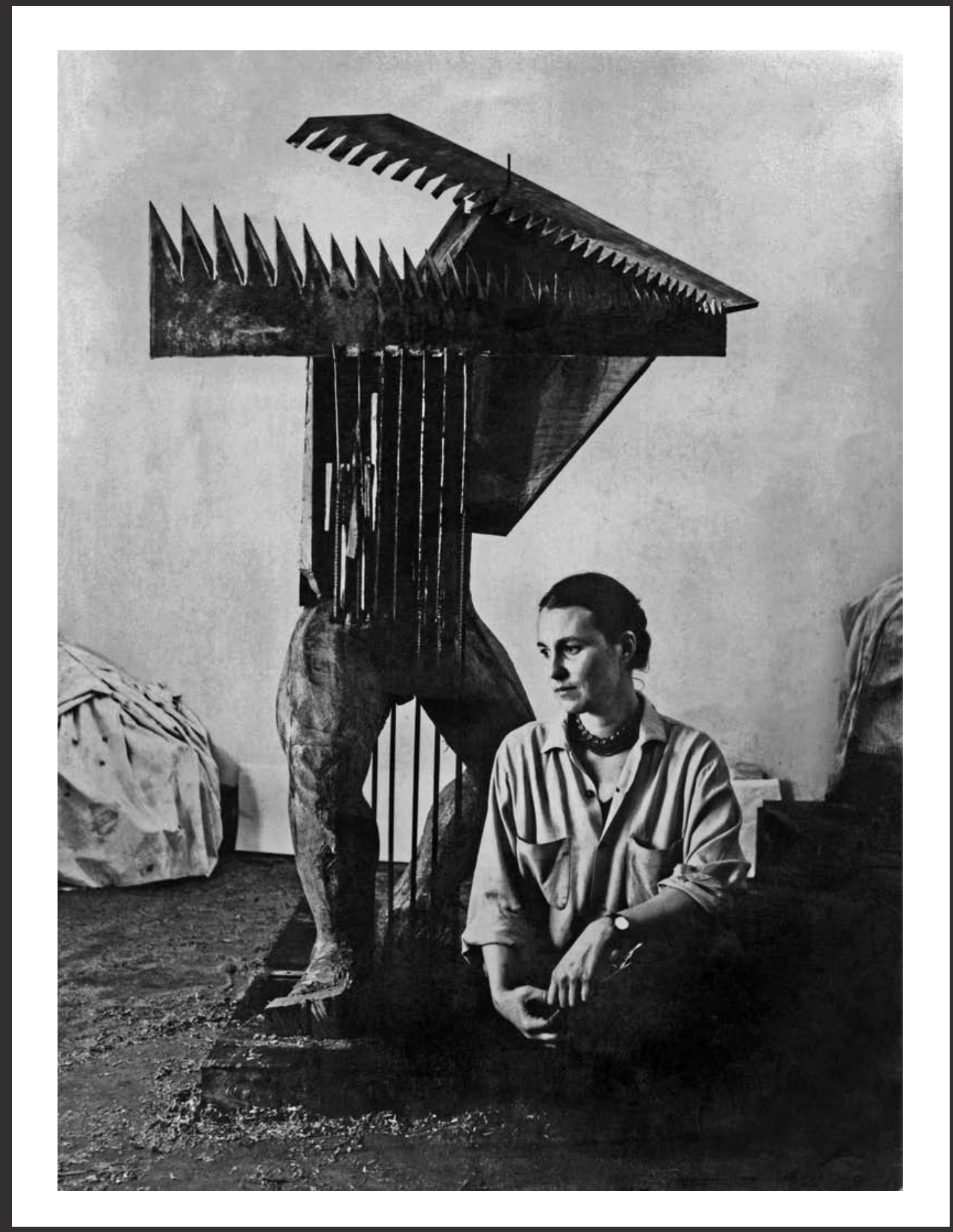

Johanna Hamman.

Foto: Alicia Benavides. Archivo: Artes Visuales Icpna. 


\section{Para Johanna Hamann a propósito de su exposición Cuerpo, frágil refugio}

Alfonso Castrillón Vizcarra

¿Cómo acercarse

a la escultora de negro

con rostro de madonna renacentista

y marcadas ojeras

de las noches desveladas?

Necesitas consultar el ideario de la pena,

la angustia del cuerpo y sus interiores,

la oquedad luminosa de la ausencia y todo lo que carga el hombre a sus espaldas.

Serio problema, imposible de resolver en dos minutos.

¿Cómo asirla, hacer que hable, dibujar sus rincones, si su pelo brillante se te escapa en la pasmosa bruma de lo relativo?

Huesos, carne, intestinos,

y otros órganos, están para decirnos que es poca la vida, un hilo de arena a punto de acabarse, un gorrión que agoniza en una rama,

iY ya!

No hay memoria y una sordera oscura nos alcanza. 